A07 ハマダラカのもつキヌレニン水酸化醇素のクローニングおよび酵素活性を有する組み換え蛋白の 発現

○松岡裕之，平井誠，王継春，石井明（自治医科大学医動物学教室）

cDNA cloning, functional expression and characterization of kynurenine 3-hydroxylase of Anopheles stephensi

Matsuoka, H., Hirai, M., Wang, J., Ishii, A.

マラリア原虫の生殖母体活性化因子（gametocyte activating factor: GAF）の本質はトリプトファンの代謝産物 であるxanthurenic acid (XA) であることが分かって来た. 我々はXAの前段階にある代謝醉素で, kynurenine を 3-hydroxykynurenine に変える醳素である, kinurenine 3-hydroxylase (K3H) をマラリア媒介蚊であるハマダ ラカ（Anopheles stephensi）からクローニングした.この遺伝子をバキュロウイルスに組み込んで昆虫細胞（Sf9）に発現させ，その醉素活性を評価した，精製したK3Hの活性は $865.6+10.5 \mathrm{nmol} / \mathrm{min} / \mathrm{mg}$ protein，至適pHは 7.0であった，RT-PCRを実施したところ本醳素は，ハマダラカにおいては, 卵・幼虫・サナギ・成虫いずれの段階 においても発現していた.

\title{
A08 Extraction method of Ascogregarina sporozoite : a potential tool of gene vector approach
}

OSudipta Roychoudhury, Mutsuo Kobayashi (National Institute of Infectious Disease)

Ascogregarina sp., the nonpathogenic parasite of Aedes sp. is expected to have the potentiality to be used as a gene vector. A comprehensive study was conducted to develop the method of extraction of sporozoites of both Ascogregarina taiwanens and As. culicis from their oocysts using the mechanical, chemical and biological method. The result revealed that the biological method enables the release of about $98 \%$ active sporozoite. The sporozoites are yield from any stage of larval midgut of Aedes species within 45 minutes to 2 hours of the ingestion. Moreover, Ascogregarina sp. showed no host specificity to be released from the oocysts. We have also found that the sporozoites are released even in the midgut of late instar larvae and attained its matured oocyst. 